\title{
Intersectionality as a tool for social movements: Strategies of inclusion and representation in the Québécois women's movement
}

\author{
Marie Laperrière \\ Department of Sociology, Northwestern University, Evanston, IL, USA
}

\section{Eléonore Lépinard}

Center for Gender Studies, Quartier UNIL-Mouline, Lausanne, Switzerland

\begin{abstract}
As a social movement strategy, intersectionality is used to foster the inclusion and representation of minority groups. In this article, we examine how Québécois women's organizations use intersectionality as a tool to include immigrant and Native women. We argue that intersectionality can entail different practices with potentially conflicting goals. We conclude that social movement scholars would benefit from paying attention to intersectionality and to how it is practiced by activists and organizations. Indeed, a focus on intersectionality sheds light on the tensions inherent in the processes by which organizations construct collective identities, formulate political demands, manage internal conflicts and build alliances.
\end{abstract}

\section{Keywords}

intersectionality, migrant women, minorities, social movements, women's organizations

Received: 23rd February 2015; Revised version received: Ist March 2016; Accepted: 3I March 2016

With roots in Black feminism and in the work of feminists of colour, the concept of intersectionality emerged as a critique of social movements' tendency to exclude minority groups' interests and identities (Collins, 1990; Crenshaw, 1991; Moraga and Anzaldúa, 1984). In fact, scholars who have studied social movements through the lens of intersectionality have exposed the widespread failure of organizations focused on a single

\footnotetext{
Corresponding author:

Marie Laperrière, Department of Sociology, Northwestern University, 1810 Chicago Avenue, Evanston, IL 60208, USA.

Email: marielaperriere20I8@u.northwestern.edu
} 
identity such as gender to address power relations among their members. They have also exposed how and why movements tend to prioritize the needs and interests of their most privileged members and to marginalize those of their most disadvantaged constituents (Crenshaw, 1991; Mohanty, 2003; Strolovitch, 2007).

In recent years, intersectionality has become a "normative goal, or preferred mode of organizing" invoked by feminists and activists from various social movements who claim to represent single identity constituencies, such as "women," in all their diversity (Weldon, 2008: 217; see also Evans, 2015). In this context, scholars have begun investigating what intersectionality means on the ground, how it is practiced by women's rights organizations, and what consequences it carries for movements, organizations, and their constituencies (e.g. Bassel and Emejulu, 2010, 2014; Jihye Chun et al., 2013; Lépinard, 2014; Townsend-Bell, 2011). However, even though recognizing or addressing intersectionality has become part of the daily practices of many activists and movements, the study of intersectionality has not been mainstreamed in social movement scholarship. ${ }^{1}$

Paying attention to practices of intersectionality can contribute to social movement scholarship in different ways. For example, scholars who have analysed the ways in which intersectionality has been adopted as a social movement strategy have shed light on the difficulties involved in forging coalitions between different groups of women and agreeing on a common political agenda (Fominaya, 2010; Gilmore, 2008; Hancock, 2011; Nyhagen Predelli and Halsaa, 2012; Rolandsen Agustín, 2013; Smith, 1995; TownsendBell, 2011; Weldon, 2006). They have also shown how movements and organizations can adopt intersectionality as an "affirmative advocacy practice" (Strolovitch, 2007) that encourages them to include political demands specifically for disadvantaged constituents into their political platforms (e.g. Giraud and Dufour, 2010; Weldon, 2006).

In this article, we contribute to this new field of research that examines intersectionality as a strategy for social movements by exploring the different, and sometimes contradictory, goals that organizations pursue when they implement intersectionality. More precisely, we distinguish between intersectionality as a tool used for the inclusion of migrant women inside organizations, and intersectionality as a tool used to reveal their political marginalization within organizations and the broader women's movement and to redress their under-representation. We explore the consequences of these two strategies for the construction of collective identity, a prime focus of social movement scholarship (e.g. Hunt and Benford, 2004; Johnston et al., 1994; Melucci, 1989; Polletta and Jasper, 2001; Taylor, 1996; Taylor and Whittier, 1992). First, we look at how women's grassroots organizations have adopted intersectionality as a tool to foster the inclusion of immigrant women into women's organizations. In this case, the goal of intersectionality is to better address immigrant women's needs in terms of service provision, and to encourage them to take part in a unified Québécois feminist project. In a second section, we analyse how the Fédération des Femmes du Québec (FFQ), a province-wide umbrella organization focused on advocacy, uses intersectionality to reveal the political marginalization of migrant and Native women and to attempt to redress it within the broader women's movement. In this case, adopting intersectionality means recognizing and addressing power relations among women. Finally, we elaborate on what an intersectional lens brings to the study of social movements. We argue that focusing on the tensions that arise when activists attempt to adopt intersectionality gives us insight into how collective identities are formed, political demands are formulated, internal conflicts are managed, and alliances are built and maintained. 
Our research relies on a combination of data from semi-structured interviews and analysis of documentation produced by women's organizations as well as observations of feminist debates during the 2015 Congrès international de recherches féministes francophones held in Montréal and in which many Québécois grassroots feminist organizations participated. The interviews were conducted by the authors in 2011 and 2012 with workers from 24 different women's organizations situated in Montreal. Organizations were selected so as to represent the variety of organizations that exist in Montréal: women's community centres, women's shelters, minority women's organizations and advocacy organizations. The data were analysed in two stages, first coded using Atlas-ti and then analysed using a grounded theory approach.

\section{Intersectionality as a tool for individual inclusion: integrating immigrant women into a common feminist project}

The Québécois women's movement is composed mostly of grassroots organizations whose strategies for social change combine service provision, advocacy work and more traditional types of protest (Dobrowolsky, 2008). Most of them are funded by the state and provide a wide variety of services such as psychosocial intervention, employment services, social activities and immigrant integration programs. The vast majority of these women's organizations, including grassroots community centres and shelters, claim a commitment to include immigrant women, and in recent years many of them have increasingly used intersectionality as a tool to make their feminist practices more inclusive.

For grassroots women's organizations in Québec, adopting intersectionality is a conscious strategy, labelled as such and aimed at fostering the inclusion of immigrant women within their organizations and within the Québécois feminist project. For a majority of organizations that are providing services to women, intersectionality is used to increase awareness of the specific needs of a variety of women. Hence, adopting intersectionality means embracing the diversity of women and making sure that the organizations respond to their needs and include them.

Numerous women's community centres have integrated intersectionality into their feminist practices by focusing on the inclusion of immigrant women at the individual level. This strategy usually means recognizing minority women's experiences and cultural differences by making sure that their specific needs are addressed in terms of service provision, and that they feel comfortable inside the organization. As an officer working in a women's centre where $25 \%$ of the women served have a migrant background summarizes:

We developed new programs to respond to [the] different needs [of migrant women]. Migrant women continuously have specific needs with regard to the various discriminations that they encounter, not only because they are women but also because they are immigrants, so they are doubly discriminated against. We did a lot of research eight years ago that enabled us to apply for funding and to develop projects and now welcoming migrant women is part of our basic mission.

As this citation suggests, intersectionality brings new concerns and new practices into women's centres that try to accommodate what are understood to be specific "needs." In this perspective, intersectionality fits with pre-existing feminist practices 
within grassroots women's organizations that focus on helping women on their own terms by letting them define what their needs are (Lépinard, 2014). Indeed, interviews abound expressing commitments to respect women's autonomy in defining their needs and goals. Intersectionality is perceived by social workers in grassroots organizations as a tool that helps them to be attuned to every woman's specific trajectory and identity. An intervention worker from a shelter explains:

When you work with the intersectional approach, of course you need to place the woman at the center ... It is the woman herself who has to define what is more oppressing for her ... Of course women experience a variety of oppressions, but here, we don't work with a theoretical discourse. We work with concrete things. We work on the ground. When women arrive here, we try to respond by letting them identify their own needs.

As this worker suggests, the adoption of intersectionality also encourages officers in these organizations to acknowledge their privileged social position within the organization and in society at large. In this process, they have to relinquish their identity as experts in order to embrace more egalitarian relationships with the women they welcome. Adopting intersectionality as part of their toolkit has thus impacted some of their organizational practices, generating new ways of thinking and doing and integrating "topics like immigration and racism in every activity we do," as an officer in a women's centre stated during her interview.

Grassroots organizations also use intersectionality in a way that fits with their other political goals. Indeed, many women's rights organizations in Quebec adhere to the Regroupement des centres de femmes du Québec, a network of women's centres that share an official feminist platform of unity focused on gender equality and solidarity among women. Being part of this network means that centres benefit from stable and equal funding from the state. In urban areas, these centres serve an important number of immigrant women and have been involved in the state project of immigrant integration. In this context, the integration of immigrant and minority women into the organization is expected to lead to their adhesion to the Québécois feminist project, and consequently to their integration into the wider Québécois society.

Using intersectionality as a tool for inclusion has an impact on the content of these organizations' political agendas. While women's centres have increasingly worked on issues that affect immigrant women, not all issues can be included in their platform. In fact, women's centres tend to emphasize the need for feminists to work on issues for which a consensus can be reached. In many cases, the desire to be inclusive translates into the avoidance of contentious issues that bring to the fore structural inequalities linked to racialization and immigration. An example of women's centres' reluctance to get involved with divisive issues is the refusal of many to take a stand on Bill 94, a 2010 project of law prohibiting religious symbols in public institutions for employees as well as service-receivers. Project 94 was a very mediatized topic that fostered vehement debates in the public sphere and inside the feminist movement. While the umbrella organization FFQ took a stand against the project, most women's centres decided not to address the issue publicly. When asked about it, the coordinator of a multicultural women's centre explains:

Have we heard about it? Yes. Did we take a stand? No. Why not? Because it is very, very complicated. When we bring up these topics, everybody becomes a little exasperated. It's not 
easy because we have women who come from everywhere ... Their opinions are on both extremes. Why the hell would we still be discussing that?

This example reflects activists' common assumption that internal conflicts should be avoided in order to preserve a common identity. In order for differences not to become politically divisive, they are framed as individual cultural differences. Hence, the need for inclusion impedes the development of alternative political discourses that could potentially highlight structural inequalities affecting immigrant women in Québec and the existence of conflicting political interests between them and white Québécois women. On the contrary, women's centres try to translate women's diverse experiences into a common feminist identity in order to build and strengthen their constituency:

At the center, we have all these educational activities that allow us to show that women's problems, which we sometimes believe are individual, are in fact collective. We show these problems to be collective so that women can realize that in the end, our condition as women leads us to experience certain things and because we are women, we all go through the same things.

As this quote suggests, women's centres recognize the importance of attending to the diversity of women's needs and identities, but they also tend to universalize women's experiences to strengthen a common identity within the organization.

The literature on intersectionality has identified several "affirmative advocacy" practices (Strolovitch, 2007) that advocacy groups might use to include minorities within their political platform. However, our study shows that inclusionary practices premised upon intersectionality do not always lead to improvement in the political representation of minority groups within the movement, that is, to a recognition of their social and political marginalization and the acknowledgment of their specific political interests as a group. Women's grassroots organizations use intersectionality as a tool for feminist intervention to foster inclusion, but this use does not entail changes to the political platform or the common identity forged by these organizations. As we show in the next section, intersectionality can be invested by social movement organizations with more ambitious, and divisive, goals.

\section{Intersectionality as a tool for political representation: recognizing conflict and building coalitions}

The FFQ is the most prominent feminist organization devoted to advocacy in Québec and serves as an umbrella for the vast majority of women's organizations across the province. It is well established and enjoys a certain amount of legitimacy in the eyes of political actors and the general population. As such, since the mid-1990s, it has had to respond to demands for inclusion from immigrant women and to critiques of its claim to politically represent all Québécois women, especially Native and migrant women. Just like women's centres, the FFQ has been working on updating its practices and analyses in order to become more inclusive. However, the meaning of inclusion and the way in which intersectionality is integrated into their feminist practice is completely different. Instead of using intersectionality as a tool to embrace diversity or to foster individual inclusion, the goal of the FFQ, in line with the theoretical roots of intersectionality, is to foster the political representation of immigrant and Native women as groups with specific identities and 
interests (Crenshaw, 1991). This aim means rethinking the common identity "women" upon which the organization is premised and critically recognizing and addressing power relations between Québécois and minority women. Hence, in recent years, activists have emphasized the importance of updating their feminist analyses in order to include new perspectives from different groups of women and to recognize how other axes of domination besides gender shape the social reality of many women's lives. Because the FFQ's strategy to integrate intersectionality into their feminist practices highlights the existence of specific political interests for minority women and acknowledges the fact that reaching consensus is not always possible, it is inherently more divisive than the strategy adopted by women's centres. In order for this strategy not to undermine the mobilization of the FFQ's constituency, activists have to focus on solidarity among women and on the claim that the amelioration of the condition of immigrant and minority women will be beneficial to all women.

In order to foster the political representation of minority women through the development of alternative discourses, the FFQ has developed diverse strategies such as encouraging immigrant organizations to become members, creating subcommittees to work on minority issues, and hiring women who are strongly involved with immigrant networks. Because the goal of adopting intersectionality is to broaden political representation rather than for all feminists to agree on a common political project, in some cases, the FFQ has also decided to recognize the importance for historically disadvantaged groups to organize on their own. For example, the Federation of Native Women from Québec decided to leave the FFQ in 1991, underlining their need to represent themselves. In 2004, the FFQ signed an official declaration of solidarity with Native women which states that the FFQ's role should be limited to supporting Native women's fights. Because the FFQ has historically positioned itself as the representative of all Québécois women, this declaration was unprecedented. An activist from the FFQ explains,

Our new ways of working with diversity have strongly influenced the way in which we see things. Our declaration of solidarity with Native women is also a way to work ... to recognize that it is possible that the entire feminist movement doesn't fit in the FFQ ... There are groups that separate themselves and say: we need to work on our specificities, even if we adhere to common rules, before being able to work with the majority. So we work in solidarity ... We don't pretend to represent Native women. We work together on common fights, but there are fights that they need to fight on their own.

The politicization of ethnic and racial identities through the mobilization of specific groups of women allows minority women to challenge power relations inside the women's movement and to propose their own perspectives on specific issues. This practice of creating an environment that fosters or at least allows for the creation of alternative discourses means that for FFQ activists, intersectional politics do not rely on the creation of a single inclusive discourse. What is described here is akin to what Weldon (2006: 57) calls "institutionalized dissent" where organizational practices reflect an expectation that disagreement will occur, a desire to encourage the development of critical perspectives, but also a commitment to a common project.

For activists from women's centres, focusing on conflicting political interests impedes solidarity among women and makes individual inclusion inside the organization difficult. While activists from the FFQ acknowledge that the recognition of divergent interests can be politically divisive, they argue that fostering the development of alternative perspectives 
serves to undo the historical invisibility of some groups of women inside the women's movement. And while consensus might not always be possible, the FFQ engages in the work of developing a common frame to understand women's condition and what is needed to change it. An activist explains how difficult this work of inclusion has been for the FFQ:

We need to know how, in the strategy, in the way we integrate political issues ... how do we do that? How do we make sure, when we work on an issue, that we didn't forget half [of the] women? How to do an analysis that still highlights common fights? It is the basis of the women's movement to work on common fights, and this hasn't changed with diversity.

Of course, the dual goal of creating a space for the development of alternative discourses and constructing a frame that allows organizations representing different groups of women to work on common fights are not always reconcilable. Hence, the adoption of intersectionality as a tool for political representation has met with important resistance. In fact, some members of the FFQ express scepticism at the idea that an intersectional approach is necessary for their daily feminist practice, and others have left the FFQ as a result of the process that led to the adoption of intersectionality. Some immigrant women have also resisted supporting the FFQ's political project that they perceive as still prioritizing "women" as the most relevant political identity. However, it is fair to say that the adoption of new strategies of political representation has led to a certain broadening of the FFQ's political agenda. In fact, the FFQ has supported demands for the adoption of laws protecting the rights of Native women, female domestic workers, victims of human trafficking and immigrant women victims of domestic violence, and for the diminution of the sponsorship time during which immigrant women are dependent on their spouses. The FFQ's strategy has also allowed for the creation of stronger connections with immigrant and ethnic women's organizations, and for demands benefitting specific subgroups of women to be supported by a larger number of organizations.

\section{Conclusion}

As our comparison of the strategies developed by Québécois women's grassroots organizations and by the FFQ shows, organizations adopt intersectionality in order to pursue different goals. While grassroots women's organizations implement intersectionality to include minority women in a unified feminist project and identity, the FFQ uses intersectionality to challenge and transform the very idea of a single feminist identity for all women. Paying attention to intersectionality and to the way in which it is practiced by activists and organizations highlights tensions inherent to processes that are central to the work of social movements. In fact, adopting intersectionality often fosters internal conflicts and shapes the way in which organizations build collective identities and formulate political demands. In order to include migrant women and maintain a common identity, grassroots organizations avoid divisive issues, depoliticize racial and religious differences and downplay power relations between women. As the case of the FFQ shows, recognizing power relations compromises the common identity of the organization and therefore meets with resistance and conflict. However, it allows for the formation of new alliances and for the inclusion of new issues on the political agenda. Hence, the different goals that organizations pursue when they adopt intersectionality come with different consequences for minority women and for the women's movement as a whole. Our analysis also shows that adopting an intersectional lens enriches social movement scholarship. 
In fact, it appears particularly fruitful to study how organizations sustain a collective identity, reorganize their political agendas and manage conflicts while attempting to recognize differences among their members.

\section{Acknowledgements}

We are grateful to the anonymous Politics reviewers and the guest editors of this special section, Silvia Erzeel and Liza Mügge, for insightful suggestions and comments on earlier drafts.

\section{Funding}

Marie Laperrière would like to thank the Social Sciences and Humanities Research Council of Canada for supporting this research, and Eléonore Lépinard gratefully acknowledges the support of the Fonds de recherche québécois société et culture for a "jeune chercheur" grant that made this research possible.

\section{Note}

1. For example, the recent Oxford handbook on social movements (Della Porta and Diani, 2015) does not devote any chapter to intersectionality.

\section{References}

Bassel L and Emejulu A (2010) Struggles for institutional space in France and the United Kingdom: Intersectionality and the politics of policy. Politics \& Gender 6(4): 517-544.

Bassel L and Emejulu A (2014) Solidarity under austerity: Intersectionality in France and the United Kingdom. Politics \& Gender 10(1): 130-136.

Collins PH (1990) Black Feminist Thought. New York: Routledge.

Crenshaw K (1991) Mapping the margins: Intersectionality, identity politics and violence against women of color. Stanford Law Review 43(6): 1241-1299.

Della Porta D and Diani M (eds) (2015) The Oxford Handbook of Social Movements. Oxford: Oxford University Press.

Dobrowolsky A (2008) The women's movement in flux. In: Smith M (ed.) Group Politics and Social Movements in Canada. Peterborough, ON, Canada: Broadview Press, pp. 159-180.

Evans E (2015) The Politics of Third Wave Feminisms: Neoliberalism, Intersectionality and the State in Britain and the US. Basingtoke: Palgrave Macmillan.

Fominaya CF (2010) Creating cohesion from diversity: The challenge of collective identity formation in the global justice movement. Sociological Inquiry 80(3): 377-404.

Gilmore S (2008) Feminist Coalitions: Historical Perspectives on Second-Wave Feminism in the United States. Champaign, IL: University of Illinois Press.

Giraud I and Dufour P (2010) Dix ans de solidarité planétaire: Perspectives sociologiques sur la Marche mondiale des femmes. Montréal: Les Éditions du remue-ménage.

Hancock A-M (2011) Solidarity Politics for Millenials: A Guide to Ending the Oppression Olympics. New York: Palgrave Macmillan.

Hunt SA and Benford RD (2004) Collective identity, solidarity, and commitment. In: Snow DA, Soule SA and Kriesi H (eds) The Blackwell Companion to Social Movements. Malden, MA: Blackwell Publishing, pp. 433-457.

Jihye Chun J, Lipsitz G and Shin Y (2013) Intersectionality as a social movement strategy: Asian immigrant women advocates. Signs 38(4): 917-940.

Johnston H, Larana E and Gusfield JR (1994) Identities, grievances, and new social movements. In: Larana E, Johnston H and Gusfield JR (eds) New Social Movements: From Ideology to Identity. Philadelphia, PA: Temple University Press, pp. 5-35.

Lépinard E (2014) Doing intersectionality: Repertoires of feminist practices in France and Canada. Gender \& Society 28(6): 877-903.

Melucci A (1989) Nomads of the Present. Philadelphia, PA: Temple University Press.

Mohanty CT (2003) Feminism without Borders: Decolonizing Theory, Practicing Solidarity. Durham, NC: Duke University Press.

Moraga C and Anzaldúa G (1984) This Bridge Called My Back: Writings by Radical Women of Color. New York: Kitchen Table. 
Nyhagen Predelli L and Halsaa B (2012) Majority-Minority Relations in Contemporary Women's Movements: Strategic Sisterhood. Basingstoke: Palgrave Macmillan.

Polletta F and Jasper JM (2001) Collective identity and social movements. Annual Review of Sociology 27(1): 283-305.

Rolandsen Agustín L (2013) Gender, Equality, Intersectionality, and Diversity in Europe. New York: Palgrave Macmillan.

Smith BE (1995) Crossing the great divides: Race, class, and gender in Southern women's organizing 19791991. Gender \& Society 9(6): 680-696.

Strolovitch DZ (2007) Affirmative Advocacy: Race, Class and Gender in Interest Group Politics. Chicago, IL: University of Chicago Press.

Taylor V (1996) Rock-a-by Baby: Feminism, Self-Help and Postpartum Depression. New York: Routledge.

Taylor V and Whittier N (1992) Collective identity in social movement communities: Lesbian feminist mobilization. In: Morris AD and Mueller CM (eds) Frontiers in Social Movement Theory. New Haven, CT: Yale University Press, pp. 104-129.

Townsend-Bell E (2011) What is relevance? Defining intersectional praxis in Uruguay. Political Research Quarterly 64(1): 187-199.

Weldon SL (2006) Inclusion, solidarity and social movements: The global movement against gender violence. Perspectives on Politics 4(1): 55-74.

Weldon SL (2008) Intersectionality. In: Goertz G and Mazur AG (eds) Politics, Gender, and Concepts: Theory and Methodology. New York: Cambridge University Press, pp. 193-218.

\section{Author biographies}

Marie Laperrière is a PhD candidate in the Department of Sociology at Northwestern University.

Eléonore Lépinard is Associate Professor in the Center for Gender Studies at the Université de Lausanne. 